\title{
The Solidarity Decade in Eastern Europe, 1980-1989: An Australian perspective
}

\section{JAN PAKULSKI AND STEFAN MARKOWSKI}

One seldom finds a consensual view among historians of recent events, but very few would object to calling the 10 years that preceded the collapse of communism in Eastern Europe the 'Solidarity Decade'. It is spanned by two crucial events, both related to the Polish Solidarity movement but also, and indirectly, sharing wider international importance. The first was the formal recognition by the communist regime of the first 'free and independent' trade union and, in reality, a powerful social reform movement in Poland in late August to early September 1980. The second event was the swearing in of the 'Solidarity government' in Poland on 12 September 1989 - the first noncommunist government since the consolidation of communist rule in 1948. The first date marks the beginning of a mass, organised social dissent that not only fatally undermined communist legitimacy in Eastern Europe, but also created a powerful collective social force capable of directing change beyond the confines of 'reformed communism' and into 'post-communism'. ' The second date marks what we call the 'Breakthrough' - a shift of emphasis from reforming to transforming the communist system, from the monopoly of power vested de jure in the Soviet-style Communist Party to the first freely elected non-communist government in the Soviet Bloc. It was a tipping point initiating the processes of the domino-like collapse of the Eastern European communist regimes.

What was remarkable about this decade - and what is worth returning to on its anniversary - was its regional and worldwide impact, which was largely unanticipated by the major actors, including Gorbachev, Wałęsa, Reagan, Bush, Kohl, Jaruzelski and Havel. We are armed now with a better historical hindsight ${ }^{2}$

\footnotetext{
1 This was acknowledged even by General Jaruzelski - for example, in an interview with Codogni (2009:301). The concept of 'post-communism' has been elaborated by Holmes (1997).

2 One should mention here recent general historical analyses and comments by Ash (2009a, 2009b); Beres and Burnetko (2009); Engel (2009); Judt (2005); Karatnycky and Ackerman (2005); Kramer (2003, 2004, 2007); Lawson (2005); Meyer (2009); and Sebestyen (2009); specific historical analyses by Codogni (2009) and Skorzyński (2009); and in memoirs by Gorbachev, Wałęsa, Jaruzelski and Geremek.
} 
that allows us to trace both the origins of the momentous year 1989-declared by Ash (2009a) 'the best year of European history' - and its impact on the subsequent chain of events, ranging from the collapse of the Soviet Union in December 1991, through socio-political emancipation of 15 new post-Soviet republics in 1991-93, to a series of political 'aftershocks' in the Philippines, South Africa, Chile, Serbia, Georgia, Ukraine, Lebanon, Kyrgyzstan, Burma and, more recently, Iran. ${ }^{3}$ While the causal connections between these 'aftershocks' and the 'negotiated regime change' - which we claim was successfully tested during the 'Solidarity Decade' - are highly diverse and complex, they are, nevertheless, quite apparent. All of these political aftershocks bore clear marks of the original Solidarity 'refolution' (Ash's term aptly describing a mixture of reform and revolution). All shared the basic 'political DNA' that can be traced to the original Solidarity model of 1980-89: a combination of massopposition carrying strong moral overtones (against injustice, lies, deceptions); wide solidary mobilisations that transcend boundaries of class, region and faith; rejection of ideological utopias - so prevalent in previous violent revolutions and radical political movements; and-perhaps most characteristically - the nonviolent forms of action backed by the principles of negotiation and compromise with political opponents. ${ }^{4}$ In spite of the divergent labels attached to these recognisable and converging paths to negotiated regime change - such as 'movement of moral renewal', 'refolution', 'velvet revolution', 'self-limiting revolution', 'peaceful revolution', 'negotiated revolution', 'coloured revolution' (orange, saffron), 'flower revolution' (tulip, rose), and so on-all of them carried a clear imprint of the successful template for non-violent transition developed and tested in Poland during the Solidarity Decade: 1980-89.

This template itself, as stressed below, has been a product of complex political evolution that occurred in Poland and in other communist countries since World War II. It included the long legacy of contestation of communist domination: the 1945-47 opposition in Poland; the 1953 revolt in East Germany; the 1956 uprisings in Poland and Hungary; protests during the Warsaw March and the Prague Spring of 1968; and, most importantly, the series of mass protests in Poland in 1970 and 1976. All these failed attempts to challenge communist domination represented a historical 'learning curve' for all those determined to contest the legitimacy of Soviet-style communism in Eastern Europe. But it was the Polish Solidarity movement in the 1980s that made it apparent that

- only the mass, solidary and coordinated protests have a chance of success

3 As pointed out by Ash (2009b), the Iranian authorities accuse the protesters against the rigged presidential election there of fomenting 'enghelab-e-makhmali', which translates as 'velvet revolution'.

4 Ash (2009b) treats these distinctive features as components of his ideal type of 'velvet revolutions of 1989' (the term applied first to the Czechoslovakian change), though he also acknowledges (1983) that the key elements of the type were articulated in Poland during the formation of Solidarity. 
- organised opposition is more likely to succeed than spontaneous and fragmented dissent

- radical regime change can be sustained only if sheltered from external (in the Polish case, Soviet) intervention

- violence is counterproductive as it only breeds more violence and favours those who command the guns (Ash 1983, 2009a, 2009b; Ascherson 1981).

As argued below, this 'transformational compound' was first synthesised in Poland in 1980 to provide philosophical direction and practical implementation tactics for a novel 'change model' exemplified by the Solidarity movement. The model was based on lessons drawn from the brutally suppressed protests in 1968, 1970 and 1976, and thus incorporated the core idea of negotiated change and political compromise, which was first articulated by Solidarity advisers in August-September 1980, and subsequently refined in the mid-1980s, mainly in underground publications by Adam Michnik (1985). The 1988 concept of the 'round table' evolved from these ideas, even though it was formally proposed by the then communist strongman General Jaruzelski. The programmatic nonviolence - a key aspect of the Solidarity 'refolution' - had largely (though probably not solely) been inspired by the powerful message of Pope John Paul II, who appealed during his first pilgrimage to Poland in June 1979 for 'defeating evil with good'. Similarly, the importance of organisation and the centrality of solidary action can be traced to the activities of the Polish 'KOR' (the Committee for the Defence of Workers) in the 1970s.

The label 'Solidarity Decade' competes with some alternative 'synthetic' descriptions of chains of events that occurred in the Soviet Bloc in the late 1980s, such as the 'Fall of the Wall', 'Collapse of Communism' and the 'Gorbachev Era'. The first two are rather bland. They suggest - misleadingly, in our view - that the key events of 1989 occurred in Germany during the famous dismantling of the Berlin Wall in November 1989, and that the main problem faced by Eastern Europe in the late 1980s was the ideological dominance of communism. Instead, we suggest that the fall of the Berlin Wall in November 1989, while of enormous symbolic value, was largely a consequence of the earlier Breakthrough in Poland (accompanied by the opening of its borders by Hungary). For all the media attention lavished on the fall of the Wall, East Germany was not the first, but the third 'domino piece'; it was tipped by the peaceful and negotiated dismantling of communist regimes in Poland and by the widely publicised mass exodus of East Germans through Hungary (and the 'freedom trains' negotiated by Poland). Without these 'tipping points' — and without the 'amber light' to reforms given by Gorbachev - the Wall would have not fallen in November 1989.

Similarly, we argue that communist ideology had lost its legitimacy in Eastern Europe long before 1989 - most apparently in Poland, as demonstrated during the 15 months of freedom in 1980-81. The socio-political liberation of 1989 
concluded the long process of ideological disenchantment with communism in general and, in particular, with its various Soviet-inspired derivatives that were often commonly and formally referred to by most Eastern European regimes as 'real socialism'. What collapsed in 1989 were the ideologically exhausted and politically discredited-and no longer Soviet-protected-'shells' of communist regimes, all commanding formidable apparatus of repression, but little or no ideological legitimacy and popular support. That collapse started in Poland in the 1970s and spread via 'political contagion' to Hungary, East Germany, Czechoslovakia, Romania, and beyond. By the 1980s, events in Poland triggered the most difficult and the most crucial phase of this collapse-creating a socio-political template for mass-supported but negotiated and (mostly) bloodless dismantling of 'real socialism'. As famously noted by Ash (1990), the accelerating impact of the Polish Breakthrough was geometric: 'what took ten years in Poland, took ten months in Hungary, ten weeks in East Germany, and ten days in Czechoslovakia.'

Finally, the label 'Gorbachev Era', while more specific in identifying a crucial actor, is also rather misleading. As stressed by most observers, Gorbachev contributed to the 1989 'refolutions' more by omission than by commissionby what he had not done (for example, sanction Soviet military interventions in Poland or East Germany), rather than by his actions. Solidarity reforms preceded Gorbachev, and subsequently radicalised his perestroika. It set the scene for changes that Gorbachev had neither intended nor anticipated. ${ }^{5}$ Moreover, the label Gorbachev era misleadingly suggests that the transformations were due to the reformist pressures 'from Moscow', which is not accurate. While the importance of Gorbachev can hardly be overestimated-and his role is given due recognition below - he was an 'unintentional leading man' in the drama of communist implosion. In other words, the dismantling of communist regimes in 1989 was an unanticipated consequence of glasnost and perestroika, both spiralling beyond the intentions of their creator. More precisely, it was the result of a fortuitous combination of a new political climate created by the Soviet leader's permissive liberalisation 'from above' (aptly described by Ash as an 'amber light' for change). It was the political Breakthrough in Poland that paved the way for post-communism in the crumbling Soviet Bloc.

The key events of the Solidarity Decade are partially depicted in this volume from the Australian perspective. This is a distinctive - and, we believe, quite

5 He was not alone; President Bush, President Mitterrand and Prime Minister Thatcher did not anticipate the radical dismantling of communist regimes, opposed the fall of the Berlin Wall, and were very apprehensive about the prospect of liberalising fragmentation of the Soviet Union. As pointed out by Ash (2009b), Gorbachev 'mistakenly believed such changes would stop at the frontier of the Soviet Union, which he saw as a country, not an internal empire'. Instead, as Kramer $(2003,2004,2007)$ shows, the revolutionary changes in Eastern-Central Europe contributed directly to the dissolution of the Soviet Union itself. Robert Conquest asked Gorbachev many years later whether, if he had known where it would all lead, he would have done the same again. He replied: "Probably not."” 
revealing — vantage point. From the distance of more than $20000 \mathrm{~km}$, from a society with a strong and old liberal-democratic tradition largely unaffected by the ideological perspectives of the Cold War, and from a continent populated by predominantly British-European migrants, the Solidarity Decade looked quite different than from adjacent and highly concerned Europe, or from the equally distant but Cold War-fixated United States. This Australian perspective is treated here as insightful rather than distortional, as a cognitive asset reflecting the advantage of refracting momentous events through the lens of a distant but interested and alert observer rather than a blurred and distorted vision imposed by the 'tyranny of geographic separation' (with apologies to Geoffrey Blainey).

This reflexive perspective combines three elements. For a start, the enormous geographic distance between Eastern Europe and Australia had muffled the noise, so to speak. From far away, one could see more clearly the main contours of events, without distracting details. The Australian commentators-both academics, such as Jan Pakulski and Martin Krygier (see below), and reflexive journalists, such as Nicolas Rothwell and Roger Boyes - provide a remarkably clear synthetic picture of developments in Poland. While acknowledging their puzzlement, they recognise the distinctive moral overtones of Solidarity's selflimiting rise and its potential implications, especially after 1985, when Solidarity pressures coincided with Gorbachev's 'amber light'.

Second, the Australian perspective appears more detached, relatively free from distortions caused by ideological clichés and rancour, as well as vested political interests, both of which tend to colour the European and American accounts. The European and American commentators, in particular, could not resist seeing the Solidarity Decade from the highly ideologised Cold War and Europe-centric perspectives - hence their frequent tendency to 'frame' it as either an episode in superpower confrontation or just 'another Polish uprising'. Similarly, many Western European commentators could not resist placing Solidarity within the old ideological pigeonholes ('trade union movement', 'reformed socialism') thus missing its distinctive and novel features.

Such ideological clichés and the accompanying political rancour-both afflicting Australian politics and public debates in the 1950s, 1960s and even 1970s - were largely gone by the early 1980s. Soviet-type socialism-an object of uncritical adulation by the Australian communists and left-leaning intellectuals during the postwar decades - was losing its lustre, especially after the invasion of Czechoslovakia and wide publicity given to the persecution of dissidents. Therefore, a few attempts to portray Solidarity as a 'rebellion against a progressive socialist regime', and the accompanying apologies for a brutal suppression of the movement in 1981 as a 'patriotic act' and a 'restoration of order', were restricted to the extremes of left and right. Most Australian analyses and commentaries in the mainstream media tended to be sober, balanced and 
detached, both politically and ideologically. They proved more sensitive to the new and original developments, such as the moral inspiration and the nonviolent character of protests - both pregnant in political consequences. This was striking in the academic analyses of Solidarity's rise (see, for example, Jan Pakulski in Part 2 of this volume), as well as in the well-informed journalistic commentaries (for example, see the reminiscences by Nicolas Rothwell, Jan Zubrzycki and Martin Krygier in Part 1 of this volume).

Finally, the Australian perspective had carried an imprint of the Polish and the Eastern European refugees. The Solidarity Decade was closely watchedand commented upon-by thousands of Polish and other Eastern European immigrants in Australia, including about 17000 new 'Solidarity refugees' who had arrived in Australia in the early 1980s. ${ }^{6}$ The impact of these 'witnessesparticipants' has infused the Australian perspective with both idealistic passion and sceptical caution. The passion reflected, above all, moral commitment typical of political refugees; the caution was a result of disappointments experienced by these refugees, especially the Solidarity émigrés (for example, see the reminiscence by Andrzej Snarski in Part 1 of this volume).

The idea for this Special Issue of Humanities Research focused on the Solidarity Decade, 1980-89, was born during the symposium The Democratic Breakthrough - 20 Years after the June 1989 Elections in Poland, which was hosted by His Excellency Andrzej Jaroszyński, the Ambassador of the Republic of Poland, and the National Europe Centre at The Australian National University (ANU) in July 2009. This Special Issue was to make several excellent papers presented at the symposium available in print. Some of these presentations were, however, personal and largely informal while others were scholarly and well researched. To capture the spontaneity and freshness of the symposium, we have decided to combine both types of presentations in a single volume. Accordingly, this Special Issue is divided into two parts. Part 1 is a collection of personal reflections and reminiscences about the Solidarity Decade by John Burgess, the Australian Ambassador to Poland from 1980 to 1984; eminent journalists Nicolas Rothwell and Jan Zubrzycki; Martin Krygier, the Gordon Samuels Professor of Law and Social Theory at the University of New South Wales, who reflects on his visits to Poland over the past 25 years; and Dr Andrzej Snarski, a direct witness of tragic events in Gdańsk in 1970 and Solidarity's 15 months of freedom in 1980-81, and, since 1983, a 'Solidarity refugee' and a prominent member of the Polish community in Australia. All these contributors illustrate the Australian perspective on the Solidarity Decade, 1980-89.

Part 2 consists of six academic contributions that provide the scholarly, substantive and refereed core of this volume. This part also covers the key

6 This was the second-largest wave of Poland-born migrants to Australia (Markowski 2009). 
aspects of the Solidarity Decade written from a scholarly perspective and grounded in academic literature. The first essay, 'The Solidarity Decade, 1980-1989', written by Polish-Australian scholar Professor Jan Pakulski of the University of Tasmania, analyses the mechanics and dynamics of the contagious systemic transformation that produced the domino-like fall of communist regimes in Eastern Europe, and that subsequently spread to some other parts of the world. The second essay, 'One Summer in Gdańsk: Poland's leadership in transition from the socialist legal model', written by Professor Murray Raft of the University of Canberra, traces the evolution of civil law and property rights in postwar Poland to infer that 'the strength of civil law institutions in transition is an important factor in the re-establishment of a liberal legal system, which contributes to the success of the transition more broadly'. The third paper, 'The Contribution of the Polish Intelligentsia to the Breakthrough of 1989', written by Dr Tracey Rowland, the Dean of the John Paul II Institute in Melbourne, focuses 'on the humanist values of the Polish intelligentsia, which were not only significant for the third miracle of 1980 but greatly contributed to the final breakthrough of the summer of 1989'. In the fourth essay, 'The Breakthrough: Polish elections in June 1989', Professor Pakulski analyses key events in Poland that directly linked with and led to the Solidarity-engineered systemic Breakthrough, and its impact on subsequent developments in the region. The fifth essay, "The "Cooperative" Mode of Dismantling Communism: From groundbreaking to ordinary', contributed by Professors Bartłomiej Kamiński of the University of Maryland and Antoni Kamiński of the Institute of Political Science, Polish Academy of Sciences, examines why Poland's early lead in political transformation 'quickly evaporated as other post-communist countries held free elections and subsequently moved faster to dismantle vestiges of communism in both polity and economy'. In the final essay, 'The European Union's Politics of Identity and the Legacy of 1989', Dr Stefan Auer of La Trobe University discusses 'the limits of EU identity politics, with a particular focus on the legacy of 1989 in Poland, Germany and Europe at large'.

We are grateful to the former Solidarity leader and President of the Republic of Poland, Lech Wałęsa, for his generous Foreword to this volume and to all the authors who contributed scholarly articles and personal reflections to this special edition of Humanities Research. We also wish to express our gratitude to His Excellency Andrzej Jaroszyński, the Ambassador of the Republic of Poland, and Professor Simon Bronitt, the then Director of the National Europe Centre at the ANU, for organising the 2009 Solidarity symposium and their subsequent support for this publication. Further, we wish to acknowledge the generous support of Witold Krzesinski, the Deputy Head of Mission, the Embassy of the Republic of Poland, who arranged for all the images reproduced in this volume to be provided courtesy of the Polish Ministry of Foreign Affairs in Warsaw; Professor Paul Pickering, Chair of the Editorial Board, and Karen Westmacott, 
Managing Editor of Humanities Research, for their support and patience; and Jan Borrie for copyediting this publication, Ursula Frederick for formatting the images, and Nausica Garcia Pinar for designing the cover.

\section{Bibliography}

Ash, T. G. 1983. The Polish Revolution: Solidarity 1980-82, Jonathan Cape, London.

Ash, T. G. 1990. Wiosna Obywateli: Rewolucja 1989 widziana w Warszawie, Budapeszcie, Berlinie i Pradze [The Springtime of the Peoples: Revolution of 1989 as seen from Warsaw, Budapest, Berlin and Prague], Polonia, Warszawa.

Ash, T. G. 2009a. '1989!', New York Review of Books, vol. 56, no. 17 (5 November).

Ash, T. G. 2009b. 'Velvet Revolution: the prospects', New York Review of Books, vol. 56, no. 19 (3 December).

Ascherson, N. 1981. The Polish August, Penguin, Harmondsworth, UK.

Beres, W. and Burnetko, K. 2009. Nasza historia: 20 lat RP [Our History: 20 years of Polish Republic], Świat Ksiażki, Warszawa.

Codogni, P. 2009. Okragky Stót, czyli Polski Rubikon [Round Table or the Polish Rubicon], Collegium Civitas/Kroszyński Media, Warszawa.

Engel, J. A. (ed.) 2009. The Fall of the Berlin Wall: The revolutionary legacy of 1989, Oxford University Press, Oxford.

Geremek, B. and Żakowski, J. 1990. Rok 1989: Geremek Opowiada, Żakowski Pyta [1989. Geremek Talks, Żakowski Asks], Plejada, Warszawa.

Holmes, L. 1997. Post-Communism. An introduction, Polity, Cambridge.

Judt, T. 2005. Postwar: A history of Europe since 1945, Penguin, New York.

Karatnytsky, A. and Ackerman, P. 2005. How Freedom is Won: From civic resistance to durable democracy, Freedom House, New York.

Kramer, M. 2003. 'The collapse of East European communism and the repercussions for the Soviet Union', [Part 1], Journal of Cold War History, vol. 5, no. 4 .

Kramer, M. 2004. 'The collapse of East European communism and the repercussions for the Soviet Union', [Part 2], Journal of Cold War History, vol. 6 , no. 4 . 
Kramer, M. 2007. 'The collapse of East European communism and the repercussions for the Soviet Union', [Part 3], Journal of Cold War History, vol. 7 , no. 1 .

Lawson, G. 2005. Negotiated Revolutions: The Czech Republic, South Africa and Chile, Ashgate, Aldershot, UK.

Markowski, S. 2009. 'Citizenship and integration: a snapshot of the Polish migrant community in Australia', Humanities Research, Special Issue: Diversity, Integration and Citizenship, vol. 15, no. 1, pp. 77-99.

Meyer, M. 2009. The Year that Changed the World, Simon \& Schuster, New York.

Michnik, A. 1985. Takie czasy, rzecz o kompromisie, Aneks, London.

Sebestyen, V. 2009. Revolution 1989: The fall of the Soviet Empire, Weidenfeld \& Nicolson, New York.

Skorzyński, J. 2009. Rewolucja Okrągłego Stołu [The Round Table Revolution], Wydawnictwo Znak, Kraków.

Wałęsa, L. 2008. Droga do Prawdy [Road to the Truth], Świat Ksiażki, Warszawa. 